\title{
Measuring Citizen Satisfaction with Public Services Delivery: Evidence from Kuwait Public Sector
}

\author{
Arafa, T. Badran ${ }^{1}$, Al-Fahad, Mohamed ${ }^{1}$, Al Ghais M. R ${ }^{1}$, Hamdy, H. I. ${ }^{2 *}$ \\ ${ }^{1}$ Kuwait University, Kuwait \\ ${ }^{2}$ MSA University, Egypt \\ Email: gfarm84hamdy@gmail.com
}

\begin{abstract}
The objectives of this study are to examine the degrees of public satisfaction with the quality of public services provided by the ministry of public work in Kuwait. As well as to identify the most important service quality indicators, that determine citizen satisfaction. We would like to emphasize that the ministry of work is just an example represents the public sector where all government organizations work under the same laws and regulations. This study administered a survey to meet these goals, where we designed, revised, and launched a structured questionnaire among 500 citizens who have been receiving services from the ministry of work. Of which only 439 questionnaires were received in completed forms, with response rate close to $87.8 \%$. Descriptive statistics, expletory factor analysis, correlation analysis, and structural equation modeling statistical techniques were employed to identify the most influential quality indicators on citizen's satisfaction with the government services. The results indicated that satisfaction with development and maintaining of infrastructure represents $69 \%$ of the sample, development and maintenance road network makes $76 \%$, employee courtesy and hospitality accounts for $63 \%$, rules and regulations explains $60 \%$, and satisfaction with ease of procedures signifies $62 \%$. Moreover, the path analysis statistical technique revealed that government rules and regulation has the most impact on overall satisfaction among other quality indicators $45 \%$, while employee's hospitality and courtesy has $38 \%$ effect, infrastructure has $20 \%$ effect, road development has $9 \%$ effect, and finally, respondents have negative $(-12) \%$ impact on overall satisfaction.
\end{abstract}

Keywords: Average variance extracted, customer satisfaction, path analysis, public services, reliability coefficient, service quality, structure equation modeling, variance explained.

\section{Introduction}

Over the last few decades, customer's satisfaction was considered as an important goal both in the private and public sectors, especially in the western countries. Thus, indispensable amount of research work in customer satisfaction, loyalty, commitments, empathy and related areas were directed to enhance and improve the supplier-customer relationships for the benefit of both parties. Researches about citizen's attitude toward public sector services were, slowed down relative to the private sector counterpart over the last decades, along with the implementation of the concept of free market philosophy, Moore (1995). This move started at the United States and western countries to demolish the philosophy of socialism led by the Soviet Union, China and other countries who follow the socialistic regime. By then, the private sector became the main service provider and undoubtedly controlled the market for most products and services Liu (2002). The unethical practices of private sector prevailed in some cases, begged the question of revising the role played by that sector. This period was characterized by exploitation of the people by maximizing profits with low quality services. In addition, ignoring the social responsibilities and obligations of improving the standard of living conditions of the citizens, uncontrolled market price, ignorance on environmental protection etc. emphasized the need of a shift towards a public sector adoption for welfare activities, Miller (2018). A shift towards activating public sector was necessary to regulate the market difficulties, to control supply and demand chain, and as a safe guard against the greed of private sector. Recently, many countries have realized the need to enhance the activities of public sector for customer protection in one hand and to monitor the environment in the other hand, Drucker (1986), Talukdarand and Meisner (2001,2010), Campbell (2012). 
Public services are services provided by governments, State governments or any government's agencies, for example, road construction, education, health care, mail services. Public services, are delivered either directly by governments or via private organizations, which is funded through public budget, Amin et. al. (2008) Public services are the responsibility of public authorities. It is the citizen's right to receive these services regardless the provider whether directly from the government or a private agencies authorized by government, as long as they meet the requirements to receive these services (Europe Commission (2005). Economists view the delivery of public services as a resource - using activities to improve public welfare. Moreover, they consider the responsibility of provision of public services as a social contract between government and citizen and could be viewed as an indicator of the health of the society, Bateson and Hoffman (2011), and Aldons (2001).

Along the same lines, satisfaction with public services delivery is the state of receiving a targeted level of utility Oliver (1997). However, many authors claim that satisfaction is an ambiguous concept because it depends mainly on how an individual perceives it, Zeithmal, Bitner, and Gremler (2018). Because people have different perceptions to the same service, hence they may give different ratings to their perception to the same services. Among popular definition of customer, satisfaction is the one given by Hunt (1991) "It is a comparison of customer expectation to perception regarding the actual service encounter". It is also true that quality is not the sole determines of customer satisfaction, but also depends on what consumers expect to receive from government, the responsibility of the authority when delivering the services and above all how the citizen are treated by the government employees, Oliver(1994), a Bateson, and Hoffman(2011).

Customer satisfaction measurements allow organizations to evaluate and assess customer's feedback regarding the services they receive. This assessment undoubtedly helps organization or government agencies to understand the key drivers, which include reliability, responsiveness, assurance, empathy, and tangibles, that create satisfaction Cohen and Brand (1993). Practical experience shows us that measuring the efficiency of the public sector via input- out relationship is not sufficient to assess the quality of the delivery system, Diagne et al. (2012). It is equally important to assess people's feedback about the quality of the products and services regularly. This can be successfully achieved by reviewing people's complaints regarding the quality of products or services or by launching periodical surveys to monitor their satisfaction. There is no doubt that, measuring customer satisfaction with service quality in particular requires monitoring several indicators of how the customer perceives levels of quality of the services, Parasurman and Colby (2015), and Eklof, and Westlund (1998), Fournier, and Mick (1999). Survey about public service is an important tool to assess the attitude of citizens towards the services offered by the Government. The results of the surveys can be used, to evaluate the existing drawbacks of the system and provide some numerical measures regarding the efficiency of the systems. These estimates of the quality indicators obtained from the survey is used to guide planning the future development and implementation of systems for the welfare of the society Thijs (2011). These measuring tools should be based on knowledge, information, and real assessment.

This research is intended to assess the degree of public satisfaction with public services provided by the ministry of work in the State of Kuwait. Moreover, it is aimed mainly to determine the most influential factors that affect the customer satisfaction. To meet these goals, a Survey study was designed and administered to collect the required data via a structured questionnaire.

\section{Material and Methods}

\subsection{Population and Sample}

The population in this study includes all citizens in Kuwait who receive public services and its affiliated agencies. However, all these ministries and governmental agencies work under the same laws and regulations. A sample of 500 citizens who have been receiving services from the ministry of work were randomly selected to participate in this study. Of which only 439 questionnaires were received in completed forms, with response rate close to $87.8 \%$.

The main dimensions included in the questionnaire are: Satisfaction with infrastructure development and maintenance, Satisfaction with road development and maintenance, Ease of paper work, Hospitality and courtesy, and the overall public satisfaction. 
Regarding the characteristics of the sample, $69 \%$ were males and $31 \%$ were females, $85.2 \%$ were Kuwaiti, and $14.8 \%$ were non-Kuwaiti, $25 \%$ were less than 25 years of age, $32.3 \%$ were between $25-35$ years old, $30 \%$ were between $35-45$ years old, $12.6 \%$ were 45 years and older. $28.9 \%$ of the respondents hold high school diploma, $63.4 \%$ were university graduated, and $7.5 \%$ were post graduated. Regarding their Geographical distribution, 21.6\% live in AlAsma, 25.5\% live in Hawali, $16.3 \%$ live in AlFarwania, $11.2 \%$ live in AlJahra, and $12.2 \%$ live in MubarakAlKabeer. We would like to point out that Kuwait has 6 states called governorates three states are considered urban and 3 states are rural. Of the sample $63.4 \%$ live in urban area and $26.6 \%$ live in rural area.

\subsection{The Research Variables}

A survey study was designed via a structured questionnaire to test public perceptions to government public services, which is summarized in the following satisfaction indicators

\section{- Infrastructure}

-Improving and maintain the network infrastructure

-Keeping the Regular maintenance

-Rainwater collection and treatment

-Wastewater treatment system

\section{- Roads network}

-Improving and maintaining roads

-Overcoming traffic jams

-Constructing bridges to enhance traffic flow

-Installing traffic signs

-Road services

- Ease of Papers work

-Ease paperwork procedures

-Ease of filing complaints

-Quick response to complains

-Feasibility of suggested solutions

- Employees Hospitality and Courtesy

-Transparence of treatment

-Friendly Welcome

-Professional treatment

\section{- Rules and Regulations}

-Following rules and standards

-Quick response and short reaction time

-Quality of performance

\section{- Overall Satisfaction}

-Satisfaction with developments and continuous improvement

-Satisfaction with public service performance

-The need for further improvement

In this context, the overall customer satisfaction is the outcome variable, while public satisfaction with infrastructure, public satisfaction with roads network development and maintenance, public satisfaction with ease of procedural work, public satisfaction with government employees treatment and hospitality, and public satisfaction with government laws and regulations are the independent variables. The main objective of this research is to identify the most influential independent variables (factors) that affect the overall citizen satisfaction with public services. In specific, we intend to verify the following set of research hypotheses: 


\subsection{Research Hypothesis}

$H_{a}$ : Satisfaction with infrastructure development and maintenance has strong positive and significant effect on overall satisfaction.

$H_{b}$ : Satisfaction with roads network development and maintenance has strong positive and significant effect on overall satisfaction.

$H_{c}$ : Satisfaction with ease of paper work and procedures has strong positive and significant effect on overall satisfaction

$H_{d}$ : Satisfaction with government employee's hospitality and courtesy has strong positive and significant effect on overall satisfaction.

$H_{e}$ : Satisfaction with government laws and regulations has strong positive and significant effect on overall satisfaction.

\subsection{Factor Analysis for Data Reduction}

Table 1. Factor analysis

\begin{tabular}{|c|c|c|c|c|c|c|c|}
\hline Constructs & \begin{tabular}{|l} 
Factor \\
Loadings
\end{tabular} & Reliability & \begin{tabular}{|l|} 
Explained \\
Variance
\end{tabular} & $\begin{array}{l}\text { Average on } 5 \\
\text { liker Scale }\end{array}$ & $\begin{array}{l}\text { Stan. } \\
\text { Error }\end{array}$ & P-value & $\begin{array}{l}\text { Degree of } \\
\text { Satisfaction }\end{array}$ \\
\hline $\begin{array}{l}\text { Developing and Maintaining Infra- } \\
\text { Structure network }\end{array}$ & & $86.9 \%$ & $79.06 \%$ & 3.0623 & 0.053 & .238 & Neutral \\
\hline $\begin{array}{l}\text { Improving and maintain the network } \\
\text { infrastructure }\end{array}$ & .919 & & & & & & \\
\hline Keeping the Regular maintenance & .930 & & & & & & \\
\hline Rainwater collection and treatment & .818 & & & & & & \\
\hline $\begin{array}{l}\text { Developing \& Maintaining Road } \\
\text { network }\end{array}$ & & $85.6 \%$ & $77.733 \%$ & 3.3005 & 0.059 & $.000^{*}$ & \multirow[t]{4}{*}{ Satisfied } \\
\hline Improving and maintaining roads & .835 & & & & & & \\
\hline Overcoming traffic jams & .912 & & & & & & \\
\hline $\begin{array}{l}\text { Constructing bridges to enhance traffic } \\
\text { flow }\end{array}$ & .896 & & & & & & \\
\hline Ease of Paper work & & $88 \%$ & $80.774 \%$ & 2.9481 & 0.048 & .282 & \multirow[t]{4}{*}{ Neutral } \\
\hline Ease paperwork procedures & .892 & & & & & & \\
\hline Ease of filing complaints & .898 & & & & & & \\
\hline Quick response to complains & .907 & & & & & & \\
\hline Friendly Welcome & & $80.2 \%$ & $71.856 \%$ & 3.1532 & 0.045 & $0.001^{*}$ & \multirow[t]{8}{*}{ Satisfied } \\
\hline Transparence of treatment & .859 & & & & & & \\
\hline Friendly Welcome & .882 & & & & & & \\
\hline Professional treatment & .800 & & & & & & \\
\hline Following Guidelines & & $91.7 \%$ & $85.777 \%$ & 2.9702 & 0.054 & .579 & \\
\hline Following rules and standards & .923 & & & & & & \\
\hline Fast response and reaction time & .945 & & & & & & \\
\hline Quality of performance & .910 & & & & & & \\
\hline Overall Satisfaction & & $73.7 \%$ & $68.042 \%$ & 3.1206 & 0.047 & $0.010^{*}$ & \multirow[t]{4}{*}{ Satisfied } \\
\hline $\begin{array}{l}\text { Satisfaction with developments and } \\
\text { continuous improvement }\end{array}$ & .640 & & & & & & \\
\hline $\begin{array}{l}\text { Satisfaction with public service } \\
\text { performance }\end{array}$ & .900 & & & & & & \\
\hline The need for improvement & .907 & & & & & & \\
\hline
\end{tabular}

* means that the mean is significantly different from three at $\alpha \leq 5 \%$.

The main objective of the factor analysis statistical technique is to reduce dimensionality of constructs if possible, remove redundancy between measurements items (instruments) in a given construct, reveal 
patterns between set of measurements and to determine what features are most important when classifying a group of items. Table(1) presents the most reliable and valid items that measure each construct the most, which includes factor loadings, Cronbach's reliability coefficient $\alpha$, the explained variance, the average of each construct measured on 5 Likert scale, the standard error and the p-value of testing the mean rating of each construct to be 3 (neutral).

Additionally, Explained variance extracted of 50\% and higher deemed acceptable. Reliability of $70 \%$ and higher ensured the internal consistency of a construct. According to Table (1) above, all items of each construct load strongly (greater than 70\%) together which satisfy the criteria for factor loading and can be an indicator of convergent validity. In addition each construct's variance is larger than $50 \%$ and each construct's Reliability is larger than 0.7. Therefore, we can confirm the internal consistency and the convergent validity of all constructs involved in the model building in subsequent sections.

\section{The Effect of Demographic Characteristics of Respondents on Perceived Satisfaction}

In this section, we investigate whether respondent's different demographic characteristics would affect their perceptions to the research variables. For example, we may question if different genders perceived the satisfaction dimensions the same or there are significant differences in perceptions between males and females citizens. We may also extend our inquiry to explore how different are they? First we express each dimension as an average of its measuring instruments; hence we test the validity of the normality assumptions to decide which test to choose whether parametric or non-parametric. However, since the sample size is reasonably large (439) we will utilize the parametric tests to assert the inquiry. The following Table (2) gives the result of the effect of gender on the research dimensions.

Table 2. Effect of gender

\begin{tabular}{|c|c|c|c|c|c|c|c|}
\hline \multicolumn{8}{|c|}{ Gender } \\
\hline & Gender & infra & Road & Ease of paper & Hospitality & Regulations & overall \\
\hline \multirow{3}{*}{ male } & Mean & 3.08 & 3.31 & 2.92 & 3.16 & 2.96 & 3.13 \\
\hline & $\mathrm{N}$ & 301 & 301 & 301 & 301 & 301 & 301 \\
\hline & Std. Deviation & 1.13 & 1.29 & 1.02 & 0.94 & 1.17 & 1.01 \\
\hline \multirow{3}{*}{ female } & Mean & 3.01 & 3.28 & 3.01 & 3.12 & 3.00 & 3.09 \\
\hline & $\mathrm{N}$ & 135 & 135 & 135 & 135 & 135 & 135 \\
\hline & Std. Deviation & 1.06 & 1.11 & 1.00 & 0.92 & 1.02 & 0.89 \\
\hline \multirow{3}{*}{ Total } & Mean & 3.06 & 3.30 & 2.95 & 3.15 & 2.97 & 3.12 \\
\hline & $\mathrm{N}$ & 436 & 436 & 436 & 436 & 436 & 436 \\
\hline & Std. Deviation & 1.11 & 1.24 & 1.01 & 0.94 & 1.13 & 0.98 \\
\hline P-value & & 0.561 & 0.561 & 0.81 & 0.393 & 0.641 & 0.714 \\
\hline
\end{tabular}

Obviously, both males and females have either positive or neutral perceptions to research variables. However, the test indicated no significant differences in their perception to each research variables.

As illustrated in Table (3) above no significant difference between urban citizen and rural citizens is noticed in their perceptions to satisfaction with roads network development and maintenance, satisfaction with ease of paper work and procedures, satisfaction with employees treatments and hospitality, satisfaction with government laws and regulation, and the overall satisfaction. However, the analysis revealed significant difference between urban and rural citizen regarding their satisfaction with infra structure. Urban citizen are less satisfied with infra structure services than the rural area (urban average rating $=2.97$, rural average rating $=3.22$, $\mathrm{p}$-value $=0.030$ ). 
Table 3. Effect of residential area

\begin{tabular}{llcccccc}
\hline \multicolumn{7}{c}{ Residential Area } \\
\hline \multicolumn{2}{c}{ Residential Area } & infra & Road & Ease of paper & Hospitality & Regulations & Overall \\
\hline \multirow{3}{*}{ Urban } & Mean & 2.97 & 3.27 & 2.96 & 3.13 & 2.99 & 3.10 \\
& $\mathrm{~N}$ & 276 & 276 & 276 & 276 & 276 & 276 \\
& Std. Deviation & 1.04 & 1.20 & 1.01 & 0.90 & 1.14 & 0.94 \\
\hline \multirow{2}{*}{2 Rural } & Mean & 3.22 & 3.37 & 2.93 & 3.20 & 2.96 & 3.16 \\
& N & 160 & 160 & 160 & 160 & 160 & 160 \\
& Std. Deviation & 1.19 & 1.28 & 1.02 & 0.98 & 1.09 & 1.03 \\
\hline \multirow{2}{*}{ Total } & Mean & 3.06 & 3.30 & 2.95 & 3.16 & 2.98 & 3.12 \\
& N & 436 & 436 & 436 & 436 & 436 & 436 \\
& Std. Deviation & 1.10 & 1.23 & 1.01 & 0.93 & 1.12 & 0.97 \\
\hline P-value & & $0.030^{*}$ & 0.419 & 0.764 & 0.479 & 0.823 & 0.499 \\
\hline
\end{tabular}

* means difference is significant at $\alpha \leq 5 \%$.

\section{Conceptual Model for Citizen Satisfaction with Public Services}

In this section, we first describe the conceptual relationship between the overall satisfaction as the outcome variable and each of the dependent variables. We hypothesized, that there is a direct positive effects of citizens satisfaction with the following constructs on the overall satisfaction: infrastructure and roads network development and maintenance, ease of paper work and procedures, employees hospitality and courtesy, and finally government laws and regulations.

\subsection{The Fitted Model}

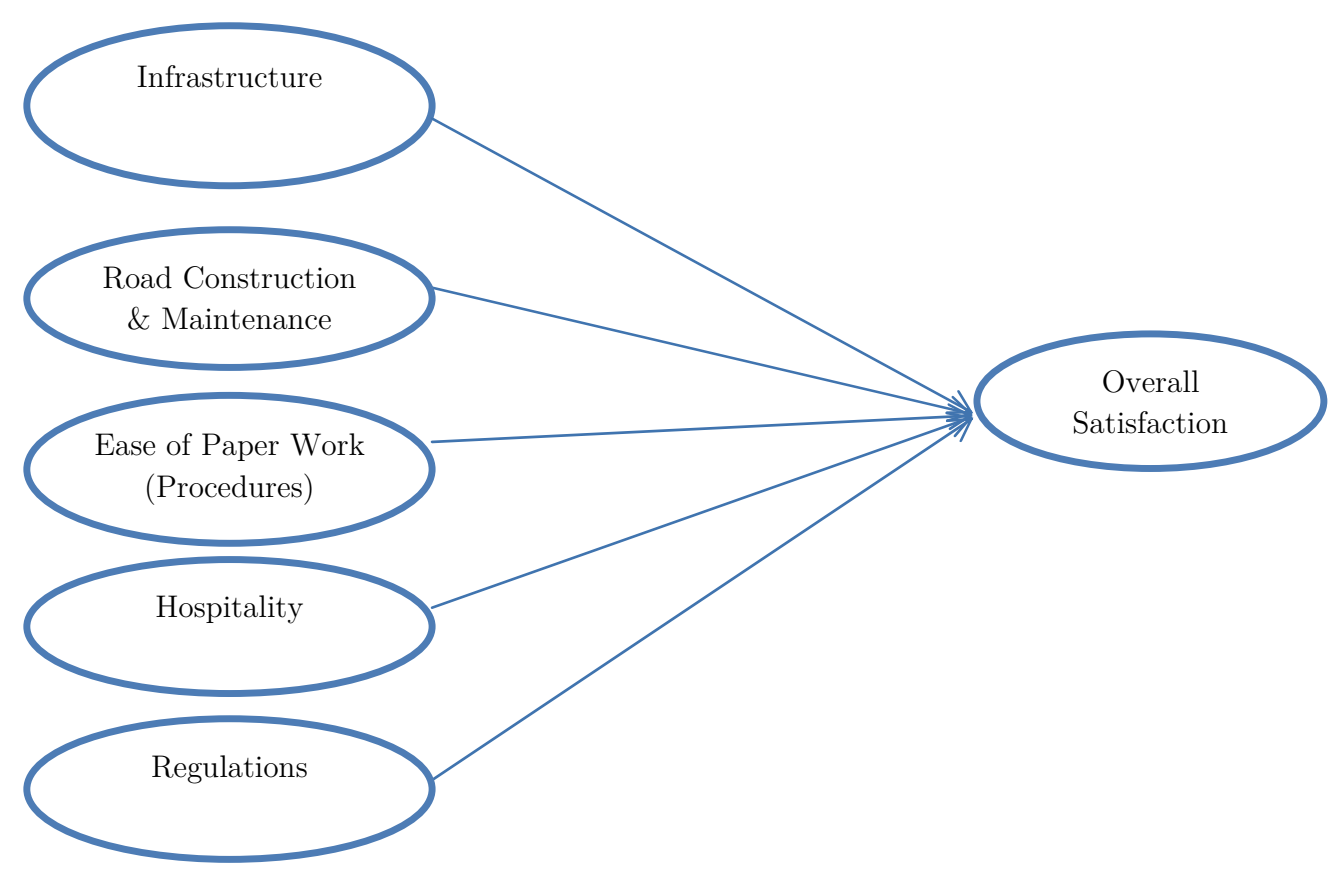

Figure 1.

Upon reaching the most reliable and valid items (instruments), to measure certain construct as illustrated in Table(4) for utilize LISREL software and the structure equation modeling technique to select the best fitted model against several alternative according to some goodness of fit criteria. Including, the Normed Fit Index $(\mathrm{NFI})=0.97$, Non-Normed Fit Index $(\mathrm{NNFI})=0.97$, Parsimony Normed 
Fit Index $(\mathrm{PNFI})=0.76$, Comparative Fit Index $(\mathrm{CFI})=0.97$, Incremental Fit Index $(\mathrm{IFI})=0.97$, Relative Fit Index $(\mathrm{RFI})=0.96$, Critical N $(\mathrm{CN})=107.86$, Root Mean Square Residual $(\mathrm{RMR})=0.075$ (supposedly less than 6\%), Standardized RMR $=0.075$, Goodness of Fit Index $(\mathrm{GFI})=0.87$ (supposedly $85 \%$ and above), Adjusted Goodness of Fit Index (AGFI) $=0.81$ (supposedly $80 \%$ or above), Parsimony Goodness of Fit Index (PGFI)=0.61(See Hair et. al.(20110) for details).

\section{The Correlation Structure between Constructs}

Table 4. The correlation matrix

\begin{tabular}{cccccc}
\hline Research Dimensions & Overall Satisfaction & Infra & Roads & Procedures & Hospitality \\
\hline Over all Satisfaction & 1.00 & & & & \\
Infra & $0.69^{*}$ & 1.00 & & & \\
p-value & 0.000 & & & & \\
Road & $0.57^{*}$ & $0.53^{*}$ & 1.00 & & \\
p-value & 0.000 & 0.000 & & & \\
Procédures & $0.78^{*}$ & $0.68^{*}$ & $0.57^{*}$ & 1.00 & \\
p-value & 0.000 & 0.000 & 0.000 & & \\
Hospitality & $0.81^{*}$ & $0.67^{*}$ & $0.51^{*}$ & $0.91^{*}$ & 1.00 \\
p-value & 0.000 & 0.000 & 0.000 & 0.000 & \\
Regulations & $0.83^{*}$ & $0.61^{*}$ & $0.58^{*}$ & $0.83^{*}$ & $0.82^{*}$ \\
p-value & 0.000 & 0.000 & 0.000 & 0.000 & 0.000 \\
\hline
\end{tabular}

* means correlation is significant at $\alpha \leq 5 \%$.

Presented in Table (4), is the correlation matrix between different constructs and the associated pvalues. Satisfaction with infra structure has strong positive and significant correlation with overall satisfaction $(\mathrm{r}=69 \%$, $\mathrm{p}$-value $=0.000)$, has strong positive and significant correlation with satisfaction with road construction $(\mathrm{r}=0.53$, $\mathrm{p}$-value $=0.000)$, has strong positive and significant correlation with ease of procedural work $(\mathrm{r}=68 \%$, p-value $=0.000)$, has strong positive and significant correlation with hospitality of the government employees $(\mathrm{r}=67 \%, \mathrm{p}$-value $=0.000)$, and has strong positive and significant correlation with government regulations $(\mathrm{r}=61 \%, \mathrm{p}$-value $=0.000)$. Satisfaction with road network developments and maintenance has a strong positive and significant correlation with ease of procedural work $(\mathrm{r}=57 \%$, $\mathrm{p}$-value $=0.000)$, has strong positive and significant correlation with hospitality of government employees $(\mathrm{r}=51 \%$, $\mathrm{p}$-value $=0.000)$, and has strong positive and significant correlation with government regulations $(\mathrm{r}=58 \%$, $\mathrm{p}$-value=0.000). Satisfaction with government laws and regulations has strong positive and significant correlation with government employees hospitality $(\mathrm{r}=91 \%$, p-value $=0.000)$, and has strong positive and significant correlation with government laws and regulations $(\mathrm{r}=83 \%$, p-value=0.000). Employees hospitality has strong positive and significant correlation with government laws and regulations $(\mathrm{r}=82 \%$, p-value $=0.000)$. Overall satisfaction has strong positive and significant correlation with road development and maintenance ( $\mathrm{r}=57 \%, \mathrm{p}-$ value $=0.000$ ), has strong positive and significant correlation with government laws and regulations $(\mathrm{r}=78 \%$, $\mathrm{p}$-value $=0.000)$, has strong positive and significant correlation with (employees hospitality $(\mathrm{r}=81, \mathrm{p}$-value $=0.000)$ and has strong positive and significant correlation with government laws and regulations $(\mathrm{r}=83 \%$, $\mathrm{p}$-value $=0.000)$.

\section{Composite Reliability (CR) \& Average Variance Extracted (AVE)}

Reaching the fitted model, which satisfies the required criteria of best fit, both composite reliability and average variance extracted of each construct can be assessed. We would like to stress that Cronbach's $\alpha$, the reliability coefficient, given in Table (1), does not ensure the unidimensionality of the construct but contrarily assumes it exists (see Hair et al., 2010 for details). Therefore, composite reliability (CR) which is a measure of internal consistency is a more reliable alternative measure and, is calculated, for each construct, by the following formula: 


$$
C R=\frac{\left(\sum \text { Standardized loadings }\right)^{2}}{\left(\sum \text { Standardized loadings }\right)^{2}+\sum \text { error } \mid}
$$

where, standardized loadings and associated errors are calculated by the structure equation technique among LISREL output.

Composite reliability of $70 \%$ or higher are considered satisfactory to ensure the consistency of a construct. On the other hand, the average variance extracted (AVE) is another measure of reliability of the construct. The AVE estimate, is the average amount of variations that a latent construct is able to explain in the observed variables to which it is theoretically represents (see Hair et al., 2010 for details). The following formula provides detailed description of its calculation, for each constructs,

$$
A V E=\frac{\left(\sum \text { Standardized loadings }\right)^{2}}{\left(\sum \text { Standardized loadings }\right)^{2}+\sum \text { error } \mid}
$$

It is common practice to consider AVE of $50 \%$ and higher as acceptable cut off value of the estimate.

As shown in Table (5), all constructs satisfy the criteria of having the AVE lager than the cut off value of $50 \%$ or higher. This ensure the internal consistency of the items of each construct in the model.

\section{Table 5 .}

\begin{tabular}{lll}
\hline Constructs & CR & AVE \\
\hline Public Satisfaction with Infra Structure & $89.87 \%$ & $75.03 \%$ \\
Public Satisfaction with Roads network & $88.92 \%$ & $72.94 \%$ \\
Public Satisfaction with Ease of Papers work & $89.94 \%$ & $74.90 \%$ \\
Satisfaction with public Treatment by Government employees & $84.10 \%$ & $63.89 \%$ \\
Public Satisfaction with Regulations & $93.83 \%$ & $83.55 \%$ \\
Overall performance & $81.49 \%$ & $61.27 \%$ \\
\hline
\end{tabular}

\section{Path Analysis and the Verification of Research Hypotheses}

Table 6. The path analysis and verification of the proposed hypotheses

\begin{tabular}{lllll}
\hline Constructs & Path Coefficient & Standard Error & t-value & p-value \\
\hline Infra Structure $\rightarrow$ Overall satisfaction & $20 \%$ & 0.05 & 3.89 & $0.000^{*}$ \\
Roads Development $\rightarrow$ Overall satisfaction & $9 \%$ & 0.04 & 2.06 & $0.019^{*}$ \\
Procedural Works $\rightarrow$ Overall Satisfaction & $-12 \%$ & 0.12 & -1.01 & 0.156 \\
Employees Hospitality $\rightarrow$ Overall Satisfaction & $38 \%$ & 0.13 & 2.92 & $0.002^{*}$ \\
Regulations $\rightarrow$ Overall Satisfaction & $45 \%$ & 0.08 & 5.57 & $0.000^{*}$ \\
\hline
\end{tabular}

* means that the effect is significant at $\alpha \leq 5 \%$.

Table (6) provides the path coefficient, its standard error, the t-value and the p-value of testing the direct effects of the 5 dimensions on the overall satisfaction. As shown in the table above infrastructure has $20 \%$ positive and significant direct effect on overall satisfaction (p-value $=0.000$ ), that supports the hypothesis $H_{a}$, Roads development has $9 \%$ positive and significant direct effect on overall satisfaction (pvalue $=0.009$ ), which affirms hypothesis $H_{b}$, employees hospitality and courtesy has $38 \%$ positive and significant direct effect on overall satisfaction (p-value 0.002 ), which confirms the hypothesis $H_{d}$, finally, regulations has $45 \%$ positive and significant effect on overall satisfaction( $\mathrm{p}$-value 0.000 ), that justifies $H_{e}$. In the contrary, procedural work has no effect on overall satisfaction (p-value $\left.=0.156\right)$, that does not support $H_{c}$. 


\section{Comments and Suggestions}

The results, generally, pointed out that citizens have neutral opinion regarding satisfaction with developing and maintaining infrastructures, and ease of paperwork and procedures. While analysis showed that, they are satisfied with developing and maintain roads work, hospitality and courtesy of public employees, and the overall satisfaction.

Regarding the effect of demographic characteristics of the respondents on their satisfactions with the research dimensions, the findings indicated that both males and females have positive perceptions towards each dimension. However, it also revealed that no significant difference between their positive perceptions. On the other hand, the t-test results indicated that urban citizens and rural citizens have no significant differences between their perceptions to road constructions, ease of paper work, hospitality and courtesy, laws and regulations and finally overall satisfaction. However, there is significant difference between their attitudes towards infrastructure. Whereas, urban citizens are less satisfied than rural citizens regarding the infrastructure services.

The path analysis results signify several facts: First, the citizens are satisfied with laws and regulations the most, curiosity comes next, Infrastructure comes third, Roads developments comes the last in satisfaction from the citizen's standpoints. It is also evident that the citizen are not satisfied with procedural work. Therefore, to increase people satisfaction we suggest regular meetings of public employees and superiors with citizen to discuss their points of dissatisfaction, reviewing complaints, conduct surveys on regular bases. It would also help to revise laws and regulations from time to time to minimize the number of steps and paperwork to finish transactions. E-government could be an efficient and effective alternative to paper work where all transaction can be done through computers, or through one window per say.

Therefore, it is the time to develop a new vision to improve the role that the public sector should play in the future to stay as a competitor to the private sector. This sort of restructuring will guarantee acceptable levels of products and services by both sectors.

\section{References}

1. Aldons, M. (2001), Responsible, representative and accountable government, Australian Journal of Public Administration, 60, 34-42.

2. Amin, S. Das, J., and Goldtien, M. eds (2008). "Are you being servied ? New tools for measuring service delivery", World Bank, Washington, D. C.

3. Bateson, J., and Hoffman (2011). Services Marketing, Fourth Edition, South -Western.

4. Campbell, B. (2012). Corporate Social Responsibility and development in Africa: Redefining the roles and responsibilities of public and private actors in the mining sector. Resources Policy (2012), 37, 138-143.

5. Cohen S. and R. Brand. (1993). Total Quality Management in Government. San Francisco, CA: Jossey-Bass.

6. Diagne, M. F., Ringold, D. and Zaidi, S.(2012). Governance and Public Service Delivery in Europe, and Central Aisa. The World Bank Europe and Central Asia Region March (2012). Poverty Reduction and Economic Management Unit. Policy Research Working Paper No: 5994.

7. Drucker, P. F. (1986). The New Meaning of Corporate Social Responsibility. California Management Review (26, 2,53 .

8. Eklof, J.A., and Westlund A. (1998). Customer Satisfaction Index and its Role in Quality Management. Total Quality Management, Taylor \&Francis.

9. European Commission (2005). Integrated guidelines 2005-2008 including a Commission Recommendation on the Broad Economic Policy Guidelines.

10. Fournier, and Mick, D. (1999). Rediscovering Satisfaction. Journal of Marketing, 63, 5-23.

11. Hair, J. F. Jr, Black, W. C., Babin, B. J., \& Anderson, R. E. (2010). Multivariate Data Analysis (7th ed.). New York: Prentice Hall.

12. Hunt, K., (1991)"Consumer satisfaction, Dissatisfaction, and Complaining Behavior". Journal of Social Issues 47,

13. Khan, H. (2010). The effect of corporate governance elements on corporate social responsibility (CSR) reporting. International Journal of Law and Management, 52, 2, 82-109.

14. Liu, P. (2002), Can Public Managers Lerne from Trens in Manufacturing Management. International Management Review-electronic Journal at http://www.ipmr.net, Volume 3, issue 2, page 44-59. 
15. Miller, R. J. (2018). Taking the greed out of Capitalism. Native Business Magazine.

16. Moore, M.H. 1995. Creating Public Value: Strategic Management in Gouvernement. Cambridge, MA: Harvard University Press.

17. Oliver, R. L. (1994) A conceptual Model of Service quality and service Satisfaction. In advances in Services Marketing and Management. Vol 2, 65-85.

18. Oliver, R. L. (1997). "satisfaction: A behavioral Perspective on the consumer (New York McGraw- Hell, page 13).

19. Parasuraman, A.and Colby, C. L. (2015). "An updated and streamlined Technology Readiness Index: TRI 2.0" Journal of Service Research 18, 59-74.

20. Talukdar, D., Meisner, C. M.( (2001). Does the Private Sector Help or Hurt the Environment? Evidence from Carbon Dioxide Pollution in Developing Countries. World Development, 29, 5, 827-840.

21. Thijs, N., (2011). Measuring to Improve: Improving Public Sector Performance by using Citizen-User satisfaction Information. European Public Administration Network ( EUPAN).

22. Zeithmal, V., Binter, M. and Gremler, M. J. (2018), Service Marketing. Seventh Ed. Mc Grow-Hill), (2003), 86 